\title{
COMT rs4680 single nucleotide polymorphism, ethnicity, and age are associated with
}

\section{fibromyalgia in women}

\author{
Polimorfismo de nucleotídeo único rs4680 no gene COMT, etnia e idade estão associadas com \\ fibromialgia em mulheres \\ El polimorfismo de un solo nucleótido rs4680 en el gen COMT, la etnia y la edad se asocian con la
} fibromialgia en las mujeres

\begin{abstract}
To investigate the influence of the catechol-O-methyltransferase enzyme (COMT) single nucleotide polymorphism (SNP) rs4680 (G/A) on fibromyalgia in women. In this observational study of case-control type 29 women with a diagnosis of FM (cases) and 31 healthy non-fibromyalgia women (controls). Sociodemographic and anthropometric data were collected, as well as data relating to Symptom Severity Scale and Generalized Pain Index and peripheral blood samples for DNA extraction; genotypic analyzes were performed by PCR-SSP. We observed that rs4680 AA genotype was more frequently observed in fibromyalgia than controls $(p=0.02)$. The A allele was also more often present in the fibromyalgia participants than in their control peers $(p=0.03)$. There was a statistically significant association between race and FM sufferers, showing that those of white ethnicity had a 2.05 times greater chance of developing the syndrome than non-white individuals $(p=0.03$; CI 95\% $0.93-4.53)$. A statistically significant correlation between age and FM was observed $(\mathrm{rS}=0.812, p=0.01)$. This study demonstrates that white women above the age of 45 , who have the AA genotype or A-allele, presents a higher risk of developing FM, showing that this polymorphism of the COMT gene may be one of the risk factors for the fibromyalgia.
\end{abstract}

Keywords: Fibromyalgia; Women; Genetic polymorphism; Pain; Catechol-O-methyltransferase.

\section{Resumo}

Investigar a influência do polimorfismo de nucleotídeo único (SNP) rs4680 (G / A) da enzima catecol-O-metiltransferase (COMT) na fibromialgia em mulheres. Métodos: Neste estudo observacional do tipo caso-controle 29 mulheres com diagnóstico de FM (casos) e 31 mulheres saudáveis sem fibromialgia (controles). Foram coletados dados sociodemográficos e antropométricos, bem como dados relativos à Escala de Severidade dos Sintomas e Índice Generalizado de Dor e amostras de sangue periférico para extração de DNA; as análises genotípicas foram realizadas por PCR-SSP. Observamos que o genótipo rs4680 AA foi mais frequentemente observado na fibromialgia do que nos controles $(p=0,02)$. $O$ alelo A também estava mais frequentemente presente nos participantes com fibromialgia do que em seus pares de controle $(p=0,03)$. Houve associação estatisticamente significativa entre raça e portadores de FM, mostrando que os de raça branca tiveram 2,05 vezes mais chance de desenvolver a síndrome do que os não brancos ( $\mathrm{p}=0,03$; IC $95 \%$ 0,93 - 4,53). Observou-se correlação estatisticamente significativa entre idade e FM (rS = 0,812, $\mathrm{p}=0,01)$. Este estudo demonstra que mulheres brancas acima de 45 anos, que possuem o genótipo AA ou alelo A, apresentam 
maior risco de desenvolver FM, mostrando que esse polimorfismo do gene COMT pode ser um dos fatores de risco para a fibromialgia.

Palavras-chave: Fibromialgia; Mulheres; Polimorfismo genético; Dor; Catecol-O-metiltransferase.

\section{Resumen}

Investigar la influencia del polimorfismo de un solo nucleótido (SNP) rs4680 (G / A) de la enzima catecol-O-metiltransferasa (COMT) sobre la fibromialgia en mujeres. En este estudio observacional de casos y controles, 29 mujeres diagnosticadas con FM (casos) y 31 mujeres sanas sin fibromialgia (controles). Se recolectaron datos sociodemográficos y antropométricos, así como datos relacionados con la Escala de Severidad de Síntomas e Índice de Dolor Generalizado y muestras de sangre periférica para extracción de ADN; Los análisis genotípicos se realizaron mediante PCR-SSP. Observamos que el genotipo rs4680 AA se observó con mayor frecuencia en la fibromialgia que en los controles $(\mathrm{p}=0,02)$. El alelo A también estuvo presente con mayor frecuencia en los participantes con fibromialgia que en sus pares de control $(p=0,03)$. Hubo una asociación estadísticamente significativa entre la raza y las personas con FM, lo que demuestra que las personas blancas tenían 2,05 veces más probabilidades de desarrollar el síndrome que las personas no blancas ( $\mathrm{p}=0,03$; IC del 95\%: 0,93 - 4,53). Hubo una correlación estadísticamente significativa entre la edad y la FM $(\mathrm{rS}=0.812, \mathrm{p}=0.01)$. Este estudio demuestra que las mujeres blancas mayores de 45 años, que tienen el genotipo AA o el alelo A, tienen un mayor riesgo de desarrollar FM, lo que demuestra que este polimorfismo del gen COMT puede ser uno de los factores de riesgo para la fibromialgia.

Palabras clave: Fibromialgia; Mujeres; Polimorfismo genético; Dolor; Catecol-O-metiltransferasa.

\section{Introduction}

The syndrome of fibromyalgia (FM) is typified by generalized chronic musculoskeletal pain and is also associated with symptoms of fatigue, sleep and mood disturbances, morning stiffness and psychological disorders (Wolfe et al., 1990). It is considered to be the second most common rheumatological disorder, affecting $2.5 \%$ of the Brazilian population (Senna et al., 2004) and approximately $2 \%$ of the world's population, primarily affecting women over 35 years of age (Wolfe et al., 1995).

The etiology of FM may be related to environmental, hormonal or genetic factors. Studies show that the pathophysiology of the syndrome is linked to abnormalities in the pain processing mechanism of the central nervous system, showing dysfunctions in neurotransmitters which can result in both under-activity of inhibitory pain pathways and hyperexcitability of pain-processing pathways. These abnormalities may be related to genetic predisposition, triggered by physical or psychological stress (Bradley \& McKendree-Smith, 2002).

Studies have associated FM with a genetic susceptibility directly related to the serotonergic, dopaminergic and catecholaminergic systems. The catechol-O-methyltransferase enzyme (COMT) works by inactivating the catecholamines and mutations in the gene that encodes this protein, and has been shown to be related to the symptoms of FM (Gursoy et al., 2003). The COMT gene may show genetic abnormalities, such as single nucleotide polymorphisms (SNPs) implicated in or related to chronic pain.

The most researched SNP of the COMT gene is Val158Met (G/A) rs4680, the literature showing that individuals carrying the A-allele have higher sensitivity to post-surgical pain ${ }^{6}$ and, fibromyalgia (Barbosa et al., 2012). A study analyzing the polymorphism of serotonin receptors and the COMT gene in patients with fibromyalgia produced significant results compared with the control group, in which patients with fibromyalgia exhibited a higher frequency for the L/L genotype (Met158Met), demonstrating that individuals with this genotype may be more susceptible to this syndrome, as this genotype encodes an enzyme incapable of metabolizing catecholamines (Matsuda et al., 2010). However, other studies found no association of chronic generalized pain or other types of chronic musculoskeletal pain with SNP in the COMT gene (Borchers \& Gershwin, 2015), illustrating that this investigation is necessary for a better understanding of the role of the polymorphism in the COMT gene in the origins and/or seriousness of FM.

The objective of the present study was to analyze the relationship between the SNP of the COMT Val158Met (G/A) rs4680 gene in women, with or without fibromyalgia. 


\section{Material and Methods}

\section{Study Design and Ethical Procedures}

The study was approved by the Human Research Ethics Committee at the Pitágoras University UNOPAR under protocol no. 1.579.152 and the individuals taking part in the study signed a Free and Informed Consent agreement.

The present study was quantitative, transversal and a case-control study (Thomas et al., 2012). A convenience sample was composed of women with FM, over 18 years old and clinically diagnosed with FM by a neurology specialist, following the 2011 guidelines from the American College of Rheumatology (ACR) (Wolfe et al., 2011). The control group was made up of women, over 18 years old, without FM, with no history of chronic pain.

Participants' sociodemographic and anthropometric data were collected, as well as data relating to physical activity, the Beck Depression and Anxiety Inventory, Visual Analog Scale (VAS) for pain, Symptom Severity Scale and Generalized Pain Index.

For the genotype analysis, peripheral blood samples were collected in a $5 \mathrm{~mL}$ Vacutainer tube containing EDTA. DNA extraction was performed based on the Salting-out protocol described by John et al. (John et al., 1991).

\section{PCR-SSP}

After DNA extraction, genotyping was performed for the G/A polymorphism of the COMT rs 4680 gene, using the polymerase chain reaction with specific primers for polymorphic sequences (PCR-SSP). The reactions were performed in a final volume of $10 \mu \mathrm{L}$ containing a $1 \mathrm{x}$ buffer, $2.5 \mathrm{mM}$ of $\mathrm{MgCL}_{2}, 10 \mathrm{mM}$ of dNTPs, $10 \mathrm{mM}$ of each primer and $1.25 \mu \mathrm{L}$ Taq polymerase DNA. The following primers were used to amplify the target fragments: COMT-A, 5'-TggTggATTTCgCTggCA3' and 5'-ACACCCATACAAgcaTTCATCAgTT-3'; and COMT-G, 5'gCATgCACACCTTgTCCTTCAC3' and 5'TgAgCATAgAggCTAAgggACCAT-3'. Cycling was as follows: heating for 1 minute at $96^{\circ} \mathrm{C}$, then at $96^{\circ} \mathrm{C}$ for 20 seconds, $70^{\circ} \mathrm{C}$ for 45 seconds for the first 5 cycles, followed by 21 cycles at $96^{\circ} \mathrm{C}$ for 25 seconds, $65^{\circ} \mathrm{C}$ for 50 seconds and $72^{\circ} \mathrm{C}$ for 30 seconds each and then 21 cycles at $96^{\circ} \mathrm{C}$ for 30 seconds, $55^{\circ} \mathrm{C}$ for 60 seconds and $72^{\circ} \mathrm{C}$ for 90 seconds, followed by a final phase of 2 minutes at $20^{\circ} \mathrm{C}$. For analysis of the results, $1 \%$ agarose gel electrophoresis was used, the size of the amplified protocol being $455 \mathrm{pb}$ for the G-allele and $322 \mathrm{pb}$ for the A-allele.

\section{Statistical Analysis}

Data was analyzed using the Statistical Package for Social Sciences (SPSS) program, version 21. Categorical variables were expressed in absolute and relative frequencies and continuous variables as means and standard deviations. The chi-squared test, Fischer's exact test and the odds ratio were used to check the association between race and genotype frequency with fibromyalgia and Kendall's $\tau$ coefficient for a correlation between fibromyalgia patients and age, with a confidence interval of $95 \%$ and a significance level of $5 \%$ being established $(\mathrm{p}<0.05)$.

\section{Results}

60 women took part in the study, 29 in the group diagnosed with fibromyalgia and 31 healthy women comprised the control group. The average age was $50.76( \pm 9.03)$ in the group with fibromyalgia and $70.32( \pm 6.86)$ in the control group, while $70 \%$ of the population were white and $68.3 \%$ exhibited some form of comorbidity. Regarding physical activity, only $22 \%$ of the participants reported practicing some type of physical activity on a regular basis. The group with the highest proportion among participants in the study had the GG genotype (58\%) and the G-allele (75\%), only 8.3\% and $25 \%$ of women having the AA genotype and the A-allele, respectively. (Table 1). 
Table 1 - Distribution of sociodemographic characteristics, physical activity, comorbidity and genotype / allele frequency in individuals with and without fibromyalgia $(n=60)$.

\begin{tabular}{|c|c|c|}
\hline Variables & $\mathbf{N}$ & $\%$ \\
\hline \multicolumn{3}{|c|}{ FIBROMYALGIA DIAGNOSIS } \\
\hline YES & 29 & 48.3 \\
\hline NO & 31 & 51.7 \\
\hline \multicolumn{3}{|l|}{ AGE } \\
\hline $32-44$ & 6 & 10.1 \\
\hline $45-65$ & 32 & 53.5 \\
\hline$>65$ & 22 & 36.8 \\
\hline Mean age $(\mathrm{M} \pm \mathrm{SD})$ & \multicolumn{2}{|c|}{$60.87 \pm 12.646$} \\
\hline \multicolumn{3}{|l|}{ RACE } \\
\hline WHITE & 42 & 70.0 \\
\hline NON-WHITE & 18 & 30.0 \\
\hline \multicolumn{3}{|l|}{ COMORBIDITY } \\
\hline YES & 41 & 68.3 \\
\hline NO & 19 & 31.7 \\
\hline \multicolumn{3}{|l|}{ PHYSICAL EXERCISE } \\
\hline YES & 13 & 22.0 \\
\hline NO & 47 & 78.0 \\
\hline \multicolumn{3}{|l|}{ GENOTYPE FREQUENCY } \\
\hline AA & 5 & 8.3 \\
\hline GG & 35 & 58.3 \\
\hline AG & 20 & 33.4 \\
\hline \multicolumn{3}{|l|}{ ALLELE FREQUENCY } \\
\hline A & 30 & 25.0 \\
\hline G & 90 & 75.0 \\
\hline
\end{tabular}

Source: Authors.

Regarding the questionnaires applied to the FM group, $89.8 \%$ of participants reported moderate to severe levels on the symptom severity scale; in the pain disability index, $89.7 \%$ reported a severe score and $72.4 \%$ reported a severe level on the visual analog scale. In the Beck depression inventory, $44.8 \%$ showed moderate to severe levels while in the anxiety inventory, $37.9 \%$ exhibited a severe level of anxiety. A total of $93 \%$ used some form of medication. (Table 2). 
Table 2 - Distribution of characteristics of FM patients. Analog Pain Scale, Symptom Severity Scale, Pain Disability Index, Beck Depression and Anxiety Inventories, medication $(\mathrm{n}=29)$.

\begin{tabular}{lcc}
\hline \multicolumn{1}{c}{ Variables } & $\%$ \\
\hline Symptom Severity Scale & 3 & 10.2 \\
Mild & 26 & 89.8 \\
Moderate to Severe & 3 & \\
\hline Pain Disability Index & 26 & 10.3 \\
Moderate & & 89.7 \\
Severe & 8 & \\
\hline Visual Analog Scale for Pain & 21 & 27.6 \\
Moderate & & 72.4 \\
Severe & 2 & 6.9 \\
\hline Beck Depression Inventory & 5 & 17.2 \\
No signs of depression & 13 & 44.8 \\
Mild to Moderate & 9 & 31.1 \\
Moderate to Severe & & \\
Severe & 4 & 13.8 \\
\hline Beck Anxiety Inventory & 6 & 20.7 \\
Minimal & 8 & 27.6 \\
Mild & 11 & 37.9 \\
Moderate & & 93.0 \\
Severe & 27 & \\
\hline Use of medication & & \\
YES & & \\
\hline & & \\
\hline
\end{tabular}

Source: Authors.

There were no statistically significant correlations in FM patients among the following variables: physical activity, visual analog scales, Beck depression and anxiety inventories, allele frequency and anthropometric data ( $p>0.05)$. However, a statistically significant association between the genotypes and FM was observed. The rs4680 AA genotype was more frequently observed in fibromyalgia than in controls [odds ratio (OR) (95\% confidence interval, $95 \% \mathrm{CI})=4.07(1.37-12.14$; $\mathrm{p}=0.02$ ). The A allele was also present in the fibromyalgia participants more often than in their non-fibromyalgia peers [OR $(95 \% \mathrm{CI})=4.03(1.65-10.27 ; \mathrm{p}=0.03 ;$ Table 3$)$.

There was a statistically significant association between race and FM sufferers, showing that those of white ethnicity had a 2.05 times greater chance of developing the syndrome than non-white individuals ( $\mathrm{p}=0.03$ ). (IC 95\% 0.93 - 4.53). A statistically significant correlation between age and FM was observed; the older patient, the greater the chance of developing the syndrome $(\mathrm{rS}=0.812, \mathrm{p}=0.01)$. 
Table 3 - Association between race and genotype frequency in individuals with and without fibromyalgia $(n=60)$.

\begin{tabular}{lccccc}
\hline Variables & \multicolumn{3}{c}{ With } & Without FM & P Value \\
& \multicolumn{2}{c}{ FM } & & & \\
\hline Race & N & \% & N & $\%$ & \\
White & 24 & 82.8 & 18 & 58.1 & 0.037 \\
Non-white & 5 & 17.2 & 13 & 41.9 & \\
Genotype Frequency & & & & & \\
AA & 5 & 17.2 & 0 & 0 & 0.010 \\
GG & 12 & 41.4 & 23 & 74.2 & \\
AG & 12 & 41.4 & 8 & 25.8 & \\
Recessive Model & & & & & \\
AA+AG & 17 & 59 & 8 & 26 & 0.010 \\
GG & 12 & 41 & 23 & 74 & \\
Allele Frequency & & & & & \\
A & 22 & 38 & 8 & 13 & 0.0014 \\
G & 36 & 62 & 54 & 87 & \\
\hline
\end{tabular}

Source: Authors.

\section{Discussion}

COMT is an enzyme involved in the process of breaking down catecholamines, which are the sympathetic neurotransmitters, through the transfer of a methyl group of S-adenosylmethionine to dopamine, noradrenaline and adrenaline in the synapses in the cerebral cortex, mainly affecting the metabolism of dopamine in the prefrontal cortex (Lachman et al., 1996), acting as a modulator of dopadrenergic, noradrenergic and adrenergic neurotransmission (Matsuda et al., 2017).

The SNP of the COMT rs 4680 gene exhibits a transition of nucleotides in codon 158, resulting in a change in the protein's aminoacids. The $\mathrm{Val} / \mathrm{Val}(\mathrm{G} / \mathrm{G})$ genotype is related to a high level of enzyme activity, while the Met/Met (A/A) genotype is related to low activity and Val/Met (G/A) to an intermediate level of activity(Matsuda et al., 2017). Lower levels of activity of this enzyme lead to a significant reduction in the dopamine levels of the postsynaptic neurons (Lachman et al., 1996).

The present study demonstrates that $17.2 \%$ of patients with FM showed a frequency of the AA (Met/Met) genotype, while no participants in the control group were seen to have it. Regarding allele frequency, 38\% of patients with FM had the A-allele while only $13 \%$ of the control group were shown to have it. Regarding the recessive model, $59 \%$ of the FM group showed low and intermediate levels of enzyme activity. Gursoy et al. (2003) found similar results in a study in which $73.8 \%$ of the population with FM had genotypes indicating low and intermediate enzyme activity (AA/GA).

Matsuda et al. (2010) also found similar results in an analysis of the COMT gene in FM, with $37.2 \%$ of patients having the polymorphic genotype. In the same study, an analysis of the relationship of the serotonin (5-HT) 2A receptor gene was conducted, but no statistically significant differences were found in relation to the syndrome.

According to Ablin and Buskila (2015), the reduction of synaptic tone related to the pathogenesis of chronic pain may be associated with the reduction of pain in FM patients. Thus several studies with genetic markers have been performed associating the metabolism of catecholamines with COMT in order to identify their role.

Inadir et al. (2014) assessed 379 FM patients and a control group composed of 290 subjects and demonstrated that the Val158Met polymorphism of the COMT gene has a positive association with the syndrome, besides playing an important role in the disorder's clinical symptoms. Similarly, Martinez-Jauand et al.(2013) reported that individuals with FM are more 
sensitive to pain than healthy volunteers after experimental painful stimuli, confirming that haplotypes of the COMT gene and genotypes of the Val158Met polymorphism play a vital role in FM patients' sensitivity to pain.

At the same time, the findings of Desmeules et al. (2014) evidenced the presence of spontaneous pain classified as moderate and severe, most probably associated with the COMT Met/Met (A/A) genotype in patients with FM. Regarding stimuli indicative of pain, inquiries pointed toward the existence of an alteration in the perception of pain due to the association of the Val158Met genotype with the temporal summation rate of the pain and the heat, possibly because the low activity of COMT causes an increased sensitivity to pain via a $\beta 2 / 3$-adrenergic mechanism.

Vagas-Arcon et al. (2007) compared six SNPs of the COMT gene (rs2097903, rs6269, rs4633, rs4818, rs4680 and rs165599) in Spanish and Mexican women with FM and observed a significant association between 3 SNPs of the COMT gene (rs6269, rs4818 and rs4680) in three Spanish female patients with FM, as they showed a greater sensitivity to pain. Loggia et al. (2011) assessed functional MRI responses to painful stimuli in 54 FM patients with the Met158Val polymorphism and found that the Met/Met (AA) genotype seems to affect brain response to pain after repeated painful stimuli.

In relation to the study limitations, the sample may have been insufficient to detect other interactions among the variables. It is possible to say that, for more assertive conclusions it is necessary to study a larger sample population and evaluate other polymorphisms of the gene combining an analysis of gene expression COMT, for further clarification. Our findings may be biologically meaningful and informative, and should be further investigated in other populations.

Concerning the clinical application of the results of the present study, the presence of association among fibromyalgia, the gene COMT, and the ethnicity and age, shows that the from these assessments it is possible to identify a genetic characteristic and some limitations of patients with this disease, thus aiding in a better therapeutic approach.

\section{Conclusions}

The present study demonstrates that white women above the age of 45, who have the AA genotype and the A-allele, have a higher risk of developing FM. Further studies are needed to confirm the present findings and it is necessary in the future researches a study with a larger sample population and evaluate other polymorphisms of the gene combining an analysis of gene expression COMT, for further clarification.

\section{Declaration of the contribution of the authors}

All authors contributed to the study conception and design. Material preparation, data collection and analysis were performed by CAMZ, LOL, SKFZ and PDOP. The first draft of the manuscript was written by KBPF and RCPF and all authors commented on previous versions of the manuscript. All authors read and approved the final manuscript.

\section{References}

Ablin, J. N., \& Buskila, D. (2015). Update on the genetics of the fibromyalgia syndrome. Best Pract. Res. Clin._Rheumatol., 9(1): 20-8.

Barbosa F. R., Matsuda J. B., Mazucato M., de Castro Franca S., Zingaretti S. M., da Silva L. M., Martinez Rossi N. M., Junior M, F., \& Marins M., Fachin A. L. (2012). Influence of catechol-O-methyltransferase (COMT) gene polymorphisms in pain sensibility of Brazilian fibromyalgia patients. Rheumatol Int., 32(2):427-430.

Borchers A. T., \& Gershwin M. E. (2015). Fibromyalgia: a critical and comprehensive review. Clin. Rev. Allergy Immunol., 49(2):100-151. Bradley L. A., \& McKendree-Smith N. L. (2002) Central nervous system mechanisms of pain in fibromyalgia and other musculoskeletal disorders: behavioral and psychologic treatment approaches. Curr Opin Rheumatol.,14:45-51.

Desmeules J., Chabert J., Rebsamen M., Rapiti E., Piguet V., Besson M., Dayer P., \& Cedraschi C. (2014). Central pain sensitization, COMT Val158Met polymorphism, and emotional factors in fibromyalgia. J Pain, 15(2): 129-35. 
Fernandez-de-las-Penas C., Fernandez-Lao C., Cantarero-Villanueva I., Ambite-Quesada S., RivasMartinez I., del Moral-Avila R., \& Arroyo-Morales M. (2012). Catechol-O-methyltransferase genotype (Val158met) modulates cancer-related fatigue and pain sensitivity in breast cancer survivors. Breast Cancer Res Treat.,133(2):405-412.

Gursoy S., Erdal E., Herken H., Madenci E., Alasehirli B., \& Erdal N. (2003). Significance of catechol-O-methyltransferase gene polymorphism in fibromyalgia syndrome. Rheumatol Int., 23(3): 104-107.

Inanir A., Karakus N., Ates O., Sezer S., Bozkurt N., Inanir S., \& Yigit S. (2014). Clinical symptoms in fibromyalgia are associated to catechol-O-methyltransferase (COMT) gene Val158Met polymorphism. Xenobiotica., 44(10): 952-6.

John S. W., Weitzner G., Rozen R., \& Scriver C. R. (1991). A rapid procedure for extracting genomic DNA from leukocytes. Nucleic Acids Res.,192: 408-408.

Lachman H. M., Papolos D. F., Saito T., Yu Y. M., Szumlanski C. L., \& Weinshilboum R. M. (1996). Human catechol-O-methyltransferase pharmacogenetics: description of a functional polymorphism and its potential application to neuropsychiatric disorders. Pharmacogenet., 6(3): $243-250$.

Loggia M. L., Jensen K., Gollub R. L., Wasan A. D., Edwards R. R., \& Kong J. (2011). The catechol-O-methyltransferase (COMT) val158met polymorphism affects brain responses to repeated painful stimuli. PLoSOne., 6(11): 27764.

Martínez-Jauand M., Sitges C., Rodríguez V., Picornell A., Ramon M., Buskila D., \& Montoya P. (2013). Pain sensitivity in fibromyalgia is associated with catechol-O-methyltransferase (COMT) gene. Eur J Pain, 17(1): 16-27.

Matsuda J. B., Barbosa F. R., Morel L. J., Franca S. C., Zingaretti S. M., da Silva L. M., Pereira A. M., Marins M., \& Fachin A. L. (2010). Serotonin receptor (5-HT 2A) and catechol-O-methyltransferase (COMT) gene polymorphisms: triggers of fibromyalgia? Rev Bras Reumatol., 50(2):141-149.

Matsuzaka C. T., Christofolini D., Ota V. K., Gadelha A., Berberian A. A., Noto C., Mazzotti D. R., SpindolaL M., Moretti P. N., Smith M. A. C., Melaragno M. I., Belangero S. I., \& Bressan R. A. (2017). Catechol-O-methyltransferase (COMT) polymorphisms modulate working memory in individuals with schizophrenia and healthy controls. Braz J Psychiatry., 39(4): 302-308.

Thomas, J. R. et al. (2012). Métodos de pesquisa em atividade física. (6ª ed.), Artmed, 2012.

Senna E. R., De Barros A. L., Silva E. O., Costa I. F., Pereira L. V., Ciconelli R. M. et al. (2004). Prevalence of rheumatic diseases in Brazil: a study using the COPCORD approach. J Rheumatol., 31:594-7.

Vargas-Alarcón G., Fragoso J. M., Cruz-Robles D., Vargas A. N., Vargas A. 1., Lao-Villadógina, J. I. et al. (2007). Catechol-O-Methyl Transferase (COMT) gene haplotypes in Mexican and Spaniard patients with fibromyalgia. Arthritis Res Ther., 9: R110.

Wolfe F., Clauw D. J., Fitzcharles M. A., Goldenberg D. L., Häuser W., Katz R. S., et al. (2011). Fibromyalgia criteria and severity scales for clinical and epidemiological studies: a modification of the ACR Preliminary Diagnostic Criteria for Fibromyalgia. $J$ Rheumatol., $38: 1113-22$

Wolfe F., Ross K., Anderson J., Russell I. J., \& Herbert I. (1995). The prevalence and characteristics of fibromyalgia in the general population. Arthritis Rheum., 38:19-28.

Wolfe F., Smythe H. A., Yunus M. B., Bennett R. M., Bombardier C., \& Goldenberg D. L. (1990). The American College of Rheumatology. Criteria for the classification of fibromyalgia: Report of the multicenter criteria committee. Arthritis Rheum, 33: 160-172. 